\title{
DEVELOPING A HARMONIOUS CULTURE-BASED SUSTAINABLE EVENT MODEL IN BALI TOURISM VILLAGE
}

\author{
I Putu ASTAWA* \\ State Polytechnic of Bali, Tourism Department, Bukiti Jimbaran, \\ Bali, Indonesia 80361, e-mail: putuastawa1@pnb.ac.id \\ Tjokorda Gde Raka SUKAWATI \\ Udayana University, Faculty of Economics and Business, \\ Bukit Jimbaran Bali, Indonesia 80361, e-mail: tjokde@unud.ac.id \\ I Nyoman Gede SUGIARTHA \\ WarmadewaUniversity, Faculty of Law, Denpasar Timur, Bali, \\ Indonesia 80361, e-mail: nyomansugiartha14@gmail.com
}

\begin{abstract}
Citation: Astawa, I.P., Sukawati, T.G.R., \& Sugiartha, I.N.G. (2019). DEVELOPING A HARMONIOUS CULTURE-BASED SUSTAINABLE EVENT MODEL IN BALI TOURISM VILLAGE. GeoJournal of Tourism and Geosites, 25(2), 446-462. https://doi.org/10.30892/gtg.25214-372
\end{abstract}

\begin{abstract}
Environmental measurement standards of various events that are easy to understand are currently still in a debate in various sustainable tourism studies. This study aims to develop an environmental measurement model based on community participation and harmonious culture in an event activity in a tourism village. This study uses two approaches, qualitative and quantitative. Event organizers are selected as the research informants to deeply explore the event implementation. The result of qualitative data processing is used as a base in questionnaire construction. Respondents are selected using stratified proportional random sampling and 82 event organizers has fulfilled the questionnaire correctly. The qualitative result indicates that belief system, cultural values, and community participation are new variables to measure green event. The quantitative result indicates that event organizers have good understanding on harmonious culture-integrated environmental measurement indicators. The trial result of the model on a case study of Cultic event finds that harmonization with God and Human dominate the event activities, whereas harmonization with environment is mostly immeasurable since the event is a traditional community- and cultural-based event. The research result contributes to the development sustainability theory, especially in environmental management. The model attributes can be developed further by adding several indicators, such as government, supplier, and the existing associations.
\end{abstract}

Key words: harmonious culture, sustainable event, tourism village

\footnotetext{
* Corresponding author
} 


\section{INTRODUCTION}

Currently, environmental issues gain more attention regarding environmentally Currently, environmental issues gain more attention regarding environmentally friendly product services (Nidumolu et al., 2009). This condition is triggered by the consumption and production patterns that damage the environment, cause the loss of biodiversity and exacerbate the consequences of climate change (Maia de Souza et al., 2013; Galli et al., 2014). Related to this matter, many environmental certification systems are developed, for example those conducted by the United Nation entitled Green Meeting Guide (UNEP et al., 2009). The book consists of a guidance to conduct environmentally friendly events with the maximum participant scale of two hundreds. Another international standard found for event activities is ISO 20121. The ISO is a sustainable management system for events that lead to environmental certification, such as world event of London Olympic 2012, the Presidential of European Union Denmark, and French Open 2014.

These efforts are directed to environmental protection issues in various tourism activities to support sustainable development. Environmental impact and environmental standardization issues have been discussed in the Earth Summit in Rio de Janeiro in 1992 that set strategies and intervention in environmental protection. The concept gives signal of order and monitoring given to the companies to be responsible to the environment. In Europe, the first European Union regulation and ISO 14001 (ISO, 1994) aim to promote a universal approach in environmental management and organizational capacity building to measure their progress related to environmental performance. Another regulation found regarding Event Sustainability Management and environmental certification for events is ISO 201. The environmental certification, however, has limitation, which is it has not included standards to evaluate the environmental impacts of an event. It is supported by the result of previous studies explained that to obtain the certification will require great effort, huge cost and continuous updated information (Martín-Pena et al., 2014; Zilahy, 2004; Liyin et al., 2006; Turk, 2009). The issues bring hesitation among companies to obtain certification and as a consequence, violations towards environmental protection.

Some countries in the world, however, have set several policies related the impact of events on environment thus it becomes a public policy that must be truly implemented and is not merely a certification (Collins \& Flynn, 2008; Getz, 2009). One of the tools used to measure environmental sustainability is Ecological Foot Print (Collins \& Flynn, 2008; Collins et al., 2009) and greenhouse gas emission model (Parkes et al., 2016). Events and environment cannot be separated in tourism development (Case, 2013) and it has been explained that there is a multi-dimensional relationship between events and environment. The relationship between event and environment has given important information on how sustainable measurement practice can be included into event planning, management, and monitoring. However, thus far there is no identical measure in measuring sustainability related to an event and only economic impact receives considerable discussions (Carlsen et al., 2001). Addressing sustainability is not merely about economy. It should consider cultural, social, and environmental aspects (Smith-Cristensen, 2009). The community should receives benefits from the event while their culture is maintained.

It will provide strengths in performing sustainable tourism. Through the concept, event organizers are encouraged to consider all the involved components including the community cultures. One of Balinese cultures is tri hita karana (harmonious culture) that maintains a balanced relationship between human and God, other human beings, and environment. The culture receives acknowledgement from UNWTO in developing tourism. In Bali, the tool is even used to assess hotel in supporting sustainable tourism (Mika, 2015; Astawa et al., 2018). The cultural acknowledgement has been stated by Pascal Lamy the head of UN-WTO in an event of Tri Hita Karana (THK) Tourism Awards \& Accreditations 
in 2015 (Buku Panduan THK, 2017). The cultural concept is used as a reference in hotel operational; however, it has not used to evaluate an event. Based on the previous explanation related to the non existence of an easy-to-understand measurement standards of event that align to the environment, the research aims to present an innovative model in environmental sustainability measurement of an event based on harmonious culture. The assessment is based on several sustainable event indicators and developed into three cultural approaches, namely: the balance of relationship with God, human, and environment. The research result is in form of a new criteria model to assess a cultural-based green event. The result is a new model, based on authors' knowledge in evaluating an event.

\section{Sustainable Event}

Currently, tourism world is closely related to events or festival activities including cultural and technological activities and it is used as an instrument to promote tourism village. Green event or sustainable event can be explained as an event that includes a sustainability element in its management practices and operation. The sustainability consists of environmental, economic, and socio-cultural responsibilities (Kapera, 2018). The three responsibilities are the foundation in developing green tourism and it requires all tourism industrial actors, such as tourist, companies, communities, and government, to play active roles (Astawa, 2018; Liu, et al., 2017). Sustainability term in event is a brand-new concept that has been studied for the past several years (Buckley, 2012; Clarke, 1997; Franzoni, 2015; Hunter, 1997; Kay et al., 2016; Lim, 2016). Research in this field is rapidly developed according to the policies of various countries to prevent the natural environment from pollution. The concept is in line with the urge of tourism actors to put environmentally friendly tourism forward (Getz, 2009; Hall, 2011; Musgrave, 2011). The goal of sustainable event is the balance of three aspects: economic, socio-cultural, and environmental dimensions (Smith-Cristensen, 2009). To produce great benefits for the societies, event organizers and the policy makers should adopt a holistic approach. The purpose is to maximize economic impacts, optimize socio-cultural effect, and minimize environmental impact.

\section{The Impact of Sustainable Event}

Events have impact on economy, social, environment, and reputation of the venue (Arnegger \& Herz, 2016; Boo \& Busser, 2005; Burgan \& Mules, 2001; Tyrrel \& Ismail, 2005). Yet, it also brings negative consequences, such as the inconveniences felt by the community at the venue where the event is conducted and an immense local government's spending to maintain the event harmonization (Fredline \& Faulkner, 2000; Kim et al., 2015). The issue cannot be measured with money since it has direct impact on the society as a whole (Andersson \& Lundberg, 2013; Chirieleison \& Montrone, 2013). The emergence of the issue triggers awareness on the environmental and social impacts to achieve sustainable tourism (Arcodia et al., 2012; Dredge \& Whitford, 2010; Getz, 2009; Hall, 2012). Several studies on events or special festivals explained that event had positive impact on the hosting area (Getz, 2008; Getz et al., 2010; Getz \& Page, 2014; Wilson \& Arshed, 2016). The event hosting area gains significant direct and indirect impacts (Bracalente et al., 2011; Dwyer et al., 2006a, 2006b; Dwyer et al., 2000a, 2000b; Lee, 2007; Lee \& Taylor, 2005; Tyrrel \& Ismail, 2005).

The economic impacts can be seen in the tourist arrival. In this case, event is a way to attract tourist; however, it is hard to predict how many people will come (Chirieleison et al., 2013; Connell et al., 2015; Felsenstein \& Fleischer, 2003; Ritchie \& Beliveau, 1974). Based on the social impact, big event activity is held to strengthen tradition or culture and has positive impact on togetherness values; however, it cannot be measured quantitatively (De Bres \& Davis, 2001; Derrett, 2003; Dwyer et al., 2000a; Kim et al., 2015; Richards, 2007). The application of Triple Bottom Line approach 
(Elkington, 1997) has increased practitioners interest in event sustainability. Event sustainability implies that event organizers should contribute to sustainable development (Hall, 2012; O'Sullivan \& Jackson, 2002; Smith-Cristensen, 2009).

A sustainable event needs to include economic, socio-cultural, and environmental goals. Therefore, sustainable event management system should set a strategy to optimize positive impacts and minimize negative impacts on social and environment (Hall, 2012; Heitmann \& Dávid, 2010; Jones, 2014; Raj \& Musgrave, 2009; Stettler, 2011; Whitson \& Horne, 2006; Yuan, 2013). Regarding the negative social impacts, it brings out various critical researches on special event and big event, especially for hosting community (Chen, 2011; Hall \& Hodges, 1996; Taks, 2013; Waitt, 2003; Whitson \& Horne, 2006).

The issue is proven by various efforts conducted in literatures to evaluate the social impacts, both qualitatively and quantitatively (Andersson \& Lundberg, 2013; Delamere, 1997; Fredline et al., 2005; Kim et al., 2015; Rollins \& Delamere, 2007; Small, 2007; Waitt, 2003). The impact include various main weaknesses occurred in the local level, among others, traffic jam and pressure on service and infrastructures causing the decrease in the utilization by the resident and the life quality of local population during the event (Hall\& Hodges, 1996; Small et al., 2005).

In addition, event organizing could generate direct cost for the community. On one hand, cultural event, in particular, often receives direct benefits from local public funding (Felsenstein \& Fleischer, 2003; Mules \& Dwyer, 2005; Whitson \& Horne, 2006). On the other hand, some costs related to organization event are indirectly supported by participation to guarantee the smoothness of the event.

These costs are likely to include overtime for the police officers, collection and cleaning fees (Chirieleison \& Montrone, 2013). The unwanted socio-cultural impacts could occur as in a case where the "tourist" of an event reduces its originality (JansenVerbeke, 2009; Thompson \& Matheson, 2008; Xie, 2004). It is a long term compromise since the event is not in accordance with the local community. In particular, when a historical commemoration and folklore become a mass product, they could lose their authentic relationship with the community, and even their reason to exist (De Bres \& Davis, 2001; Derrett, 2003; McCartney \& Osti, 2007; Richards, 2007).

As for negative environmental impacts, special event could determine the use of energy and natural resources intensively and produce atmospheric pollution and water pollution not to mention the increase in waste and noise (Adema \& Roehl, 2010; Hottle et al., 2015; Kulshrestha et al., 2004; Kuo et al., 2006; Wang et al., 2007). For example, recently, a mega-event is accused to be responsible for the contribution to climate change (Collins et al., 2009; Dolles \& Söderman, 2010). Various methodologies have been proposed in literatures to evaluate and measure the environmental impacts of organization events, such as ecological footprint (Collins \& Flynn, 2008; Dolf \& Teehan, 2015; Gössling et al., 2002; Wackernagel \& Rees, 1998), environmental impact assessment (Ahmed \& Pretorius, 2010; Hunter \& Green, 1995; Tang et al., 2009), carrying capacity (Lee \& Graefe, 2003; Lindberg et al., 1997; O'Reilly, 1986), and environmental input-output table (Collins et al., 2009). Following the rapid spread of research development for event sustainability, it progressively drives the attention of the organizers and policy makers to responsible event management (Arcodia et al., 2012; Dredge \& Whitford, 2010; Gaffney, 2013; Okech, 2011).

\section{Sustainable Event Measurement}

The research result explains that there are various indicators used to measure the environmental impact of an event. Indicators used to represent sustainability are location, energy, water resources, catering, promotional giveaways, materials, internal travel, waste management and participatory approach (Boggia et al., 2018). 
Another view states that location is the key in calculating sustainable event (Raj \& Musgrave, 2009). In addition, green food, Material Natural, Waste management, Ecosystem, and culture are the important indicators to hold a green event (Astawa et al., 2018). Assessment indicators in sustainable event are explained in (Table 1).

Table 1. Indicators of sustainable event assessment (Source: previous research, 2018)

\begin{tabular}{|c|c|c|c|c|}
\hline Variable & Item & Detail item & Unit & Source \\
\hline \multirow{3}{*}{ Location } & Area Saved space used & \multirow{3}{*}{ Saved space used } & $\%$ & \multirow{3}{*}{$\begin{array}{c}\text { Boggia et al. 2018; } \\
\text { Raj \& Musgrave, } \\
2009 .\end{array}$} \\
\hline & Tensile tructures & & yes/no & \\
\hline & Signage & & yes/no & \\
\hline \multirow{4}{*}{ Energy } & Environmental certification & Electricity saved & $\%$ & \multirow{4}{*}{ Boggia et al., 2018} \\
\hline & Energy classification score & Renewable energy & $\%$ & \\
\hline & \multirow{2}{*}{ Energy consumption } & Fuels saved & $\%$ & \\
\hline & & Electricity generators & yes/no & \\
\hline \multirow{2}{*}{$\begin{array}{c}\text { Water } \\
\text { management }\end{array}$} & \multirow{2}{*}{ Water saved } & Non-potable & $\%$ & \multirow{2}{*}{ Boggia et al., 2018} \\
\hline & & Drinking & $\%$ & \\
\hline \multirow{13}{*}{ Catering } & Company & Zero km company & $\%$ & \multirow{13}{*}{$\begin{array}{c}\text { Boggia et al., } 2018 \\
\text { Astawa et al.,2018 } \\
\text { Leuenberger \& } \\
\text { Jungbluth, 2009; } \\
\text { FAO, 2013. }\end{array}$} \\
\hline & \multirow{3}{*}{ Materials } & Eco-friendly materials & $\%$ & \\
\hline & & Eco-friendly dishes & yes/no & \\
\hline & & Packaging & $\%$ & \\
\hline & \multirow{9}{*}{ Food and beverages } & Organic products & $\%$ & \\
\hline & & Fair trade products & $\%$ & \\
\hline & & Seasonal products & $\%$ & \\
\hline & & Zero km products & $\%$ & \\
\hline & & Fruit and vegetables & $\%$ & \\
\hline & & $\begin{array}{l}\text { Bread, pasta, } \\
\text { rice and by-products }\end{array}$ & $\%$ & \\
\hline & & Animal products & $\%$ & \\
\hline & & Certified fish & yes/no & \\
\hline & & Food wastage & $\%$ & \\
\hline \multirow{5}{*}{$\begin{array}{l}\text { Promotional } \\
\text { giveaways }\end{array}$} & \multirow{2}{*}{ Non-food } & Eco-friendly products & $\%$ & \multirow{5}{*}{$\begin{array}{l}\text { Boggia et al., } 2018 \\
\text { Astawa et al.,2018 }\end{array}$} \\
\hline & & Fair trade products & $\%$ & \\
\hline & \multirow{3}{*}{ Food } & Organic products & $\%$ & \\
\hline & & Zero km products & $\%$ & \\
\hline & & Seasonal products & $\%$ & \\
\hline \multirow{9}{*}{ Materials } & Packaging & No plastics & $\%$ & \multirow{9}{*}{$\begin{array}{l}\text { Boggia et al., 2018; } \\
\text { Astawa et al.,2018 }\end{array}$} \\
\hline & \multirow{2}{*}{ Flowers/plants } & Endemic seasonal species & $\%$ & \\
\hline & & Zero km & $\%$ & \\
\hline & \multirow{3}{*}{$\begin{array}{l}\text { Paper, brochures and } \\
\text { documents }\end{array}$} & $\begin{array}{l}\text { Recycled/environmentally } \\
\text { certified paper }\end{array}$ & $\%$ & \\
\hline & & Electronic format & $\%$ & \\
\hline & & Double-sided printing & $\%$ & \\
\hline & \multirow{2}{*}{ Detergents } & Eco-friendly products & $\%$ & \\
\hline & & Other Eco-friendly products & $\%$ & \\
\hline & Others & Reused and reusable products & $\%$ & \\
\hline \multirow{2}{*}{$\begin{array}{c}\text { Internal } \\
\text { travel }\end{array}$} & \multirow{2}{*}{ Packaging } & On foot/public transport/car sharing & $\%$ & \multirow{2}{*}{$\begin{array}{l}\text { Boggia et al., 2018; } \\
\text { Astawa et al., } 2018\end{array}$} \\
\hline & & By car & $\%$ & \\
\hline $\begin{array}{c}\text { Waste } \\
\text { management }\end{array}$ & Activities & Separate collection & \% yes & $\begin{array}{l}\text { Hottle et al., 2015. } \\
\text { Boggia et al., 2018; } \\
\text { Astawa et al.,2018 }\end{array}$ \\
\hline $\begin{array}{c}\text { Participatory } \\
\text { approach }\end{array}$ & Activities & Question & \% yes & $\begin{array}{l}\text { Boggia et al., 2018; } \\
\text { Astawa et al., 2018 }\end{array}$ \\
\hline Culture & Activities & Question & \% yes & Astawa et al., 2018 \\
\hline
\end{tabular}




\section{Harmonious Culture}

Hofstede (1991) prefers to define culture as a pattern of thinking, feeling, and action of a social group that differentiate them from other social groups. Siagian (2002) defines organizational culture as refers to a shared meaning system followed by members of the organization that differentiate the company to other companies. Organizational culture has been characterized by community culture where the company is established (Windia \& Ratna, 2007). One culture originated from local community is harmonious culture. The culture put harmonious relationship with God, human, and environment forward to achieve happiness. It is sourced from community tradition and has been set as the foundation of business principles, tourism development philosophy, spatial arrangement, and strategic plan for Bali region development (Peraturan Daerah No. 16/2002). Initially, it is used as guidance by pekraman village (traditional village) and farmers in subak irrigation system (agriculture) in Bali. In its development, the concept has been used in tourism business and receives acknowledgement from the Pacific Area Travel Association (PATA) and World Tourism Organization (WTO). The culture is one of national culture that contains universal values and it does not recognize differences in ethnicity, race, and religion in its concept and implementation (Windia \& Ratna, 2007). The comparison of harmonious culture and Schein's culture (2004) is explained in (Table 2).

Table 2. The Comparison of Schein's Culture (2004),

Harmonious Culture, and Harmony Sub-culture (Source: Astawa \& Sudika, 2014)

\begin{tabular}{|c|c|c|}
\hline Schein (2004) & Harmonious Culture & Harmonious Sub-culture \\
\hline Basic Assumption & Parahyangan & Pray and honesty \\
\hline Value System & Pawongan & $\begin{array}{c}\text { Work hard, mutual cooperation (gotong royong) and } \\
\text { love each other (tatwamasi) }\end{array}$ \\
\hline Artifact & Palemahan & Clean and Green \\
\hline
\end{tabular}

\section{MATERIALS AND METHODS}

The research used qualitative and quantitative approaches (exploratory sequential design) (Creswell \& Clark, 2017). Data collection technique was conducted using interview and questionnaire. In-depth interview was conducted to event organizers that organize an event in tourism villages in Bali Province. The organizer consisted of travel agent, accommodation (hotel), restaurant, academics, and government. Prior to the interview, a letter was sent to the event organizers by post or email consisted of the application of harmonious culture in green event indicators. The selection of key informants was based on event organizer that conducted the most green event and recommendation from the head of the tourism village. Fifteen informants were selected and the interview was conducted about 55 minutes, on average.

Data collection was conducted from February to May 2018. Data collected were compared to green event theory (Glaser \& Strauss, 2017) and data coding was conducted based on Miles \& Huberman (1994). The qualitative result was used to build questionnaire consisted of three aspects, namely: green event that is in harmony with God, green event that is in harmony with human, and green event that in harmony with the nature (Boggia et al., 2018; Astawa et al., 2018; Raj \& Musgrave, 2009; Leuenberger \& Jungbluth, 2009; FAO, 2013). The questionnaire was previously tested to determine the validity and reliability of its items. The valid questionnaire were distributed through email to 82 event organizers, as respondents, that were selected using Stratified Proportional Random Sampling (Hair et al., 2016). It aimed to test the event organizer understanding on green event. The respondents consisted of 36 travel agents, 24 accommodation (hotel), 12 restaurants, six academics, and four governments. 
The questionnaire was used as a model to measure the implementation of an environmentally sound event, which was an event organized by an education institution, State Polytechnic of Bali, in Pinge tourism village. The event was Culture and Tourism International Camps (Cultic) with participant of 147 people (Astawa, et al., 2018). The research design can be explained in (Figure 1).

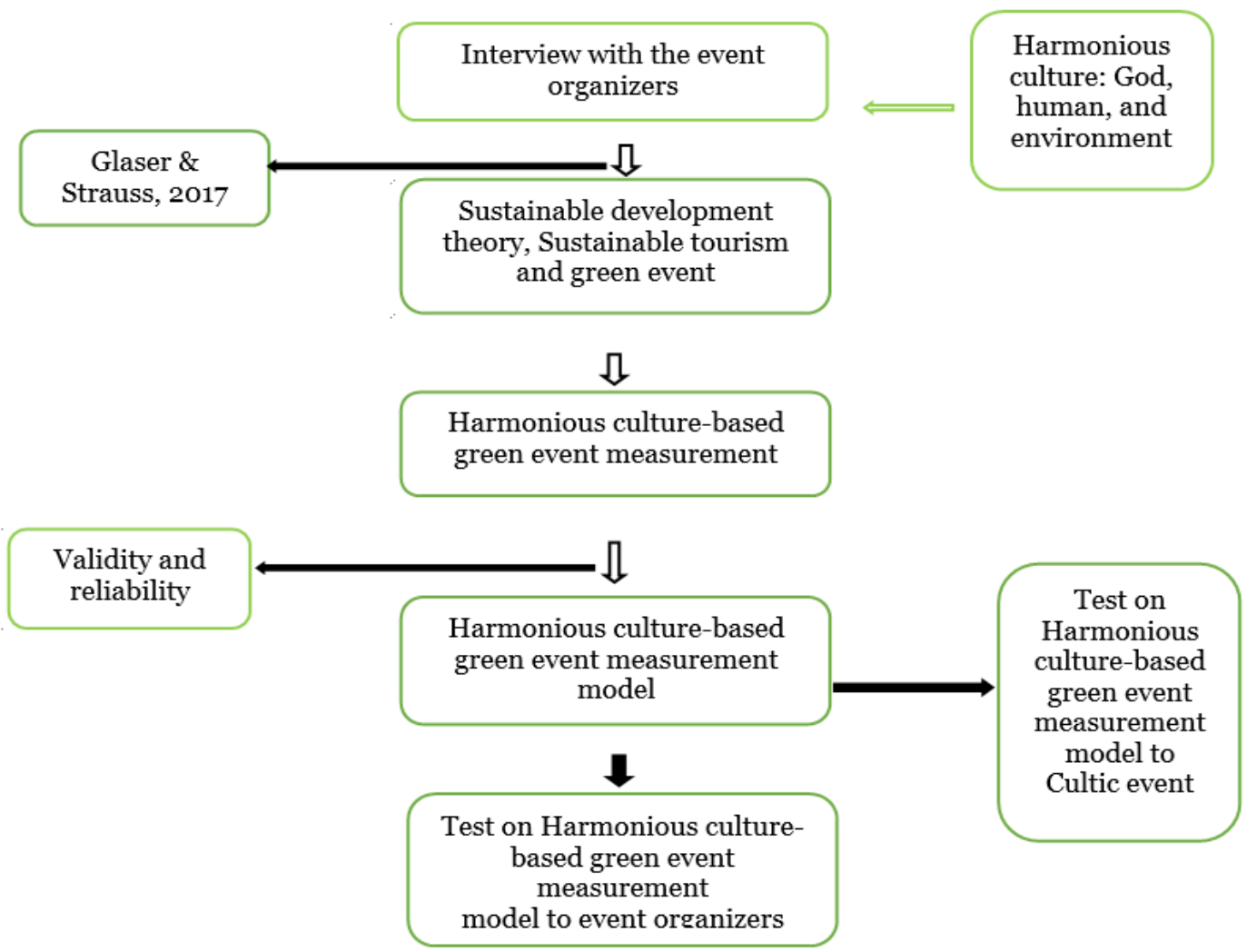

Figure 1. Researsch Design (Source: Creswell \& Clark, 2017)

\section{RESULTS DISCUSSIONS}

The result of qualitative study is explained in (Table 3).

Table 3 indicates that through harmonious approach with God, green event was measured using two variables, namely belief system and cultural values variables. The assessment method was by looking at the togetherness program that believed in the existence of God including prayer. The assessment on cultural values variable was conducted by measuring the involvement of event participants in maintaining the cultural values. It included, one of them, being involved in the existing cultural events in the tourism village. The approach of harmonious culture with human in the event revealed variables of internal travel, participatory approach, and villagers. In these variables, the measurement was conducted on the use of transportation mode in the internal event, the involvement of the event participants in supporting green event and the involvement of community in the event implementation. In detail, the measurement would assess the transportation mode used, such as on foot, using public transportation, sharing with friends, using car, and using bicycle and all parties, including the villagers, supported the implementation of event that align to the environment. The result of the two different cultural approaches 
were different from the results of studies conducted by several researchers, such as Boggia et al., 2018; Raj \& Musgrave, 2009; Leuenberger \& Jungbluth, 2009.

Table 3. Result of Qualitative Data Processing

of Harmonious Culture-Based Green event (Source: processed data, 2018)

\begin{tabular}{|c|c|c|c|}
\hline $\begin{array}{l}\text { Harmonious } \\
\text { culture }\end{array}$ & $\begin{array}{l}\text { Green Even } \\
\text { Variable }\end{array}$ & Item & Detail item \\
\hline \multirow[b]{2}{*}{$\begin{array}{l}\text { Harmony } \\
\text { with God }\end{array}$} & Belief system & Prayer & Congregation \\
\hline & Cultural values & $\begin{array}{l}\text { Understanding of village } \\
\text { customs }\end{array}$ & $\begin{array}{c}\text { Involvement in customary } \\
\text { activities }\end{array}$ \\
\hline \multirow{3}{*}{$\begin{array}{l}\text { Harmony } \\
\text { with human }\end{array}$} & Internal travel & The use of transportation & On foot/public transport/car sharing \\
\hline & $\begin{array}{l}\text { Participatory } \\
\text { approach }\end{array}$ & $\begin{array}{c}\text { Event participants } \\
\text { Activities }\end{array}$ & $\begin{array}{c}\text { By car } \\
\text { By bicycle }\end{array}$ \\
\hline & Villagers & Villagers activities & Green support \\
\hline \multirow{38}{*}{$\begin{array}{c}\text { Harmony } \\
\text { with the } \\
\text { natural } \\
\text { environment }\end{array}$} & \multirow{4}{*}{ Location } & \multirow{2}{*}{ Area Saved space used } & Saved space used \\
\hline & & & Holy/sacred places \\
\hline & & Tensile structures & Have removable plastic \\
\hline & & Signage and communication & The eco-sustainability of the event \\
\hline & \multirow{6}{*}{ Energy } & Environmental certification & Good practices for the use of energy \\
\hline & & Energy classification score & Enrgy classification of the location \\
\hline & & \multirow{4}{*}{ Energy consumption } & Electricity saved \\
\hline & & & Renewable energy \\
\hline & & & Fuels saved \\
\hline & & & Electricity generators \\
\hline & Water management & Water saved & Non-potable Drinking \\
\hline & \multirow{13}{*}{ Catering } & Catering company & Zero km company \\
\hline & & \multirow{3}{*}{ Materials } & Eco-friendly materials \\
\hline & & & Eco-friendly dishes \\
\hline & & & Packaging \\
\hline & & \multirow{9}{*}{ Food and beverages } & Organic products \\
\hline & & & Fair trade products \\
\hline & & & Seasonal products \\
\hline & & & Zero $\mathrm{km}$ products \\
\hline & & & Fruit and vegetables \\
\hline & & & Bread, pasta, rice and by products \\
\hline & & & Animal products \\
\hline & & & Certified fish \\
\hline & & & Food wastage \\
\hline & \multirow{5}{*}{$\begin{array}{l}\text { Promotional } \\
\text { giveaways }\end{array}$} & \multirow{2}{*}{ Non-food } & Eco-friendly products \\
\hline & & & Fair trade products \\
\hline & & \multirow{3}{*}{ Food promotion giveaway } & Organic products \\
\hline & & & Zero km products \\
\hline & & & Seasonal products \\
\hline & \multirow{8}{*}{ Materials } & Food Packaging & No plastic \\
\hline & & Flowers/plants & Endemic seasonal species \\
\hline & & & Zero km \\
\hline & & \multirow{3}{*}{$\begin{array}{l}\text { Paper, brochures and } \\
\text { documents }\end{array}$} & $\begin{array}{l}\text { Recycled/environmentally } \\
\text { Certified paper }\end{array}$ \\
\hline & & & Electronic format \\
\hline & & & Double-sided printing \\
\hline & & \multirow{2}{*}{ Detergents } & Eco-friendly products \\
\hline & & & Other Eco-friendly products \\
\hline & Waste management & Waste management & Reused and reusable products \\
\hline
\end{tabular}


The differences were related to belief system, cultural values, and villagers variables. The differences supported a research result by Hofstede (1983) that belief system-related culture is given in nature in European countries and it requires no explanation and is attached in the behavior. This research were mostly referred to European sources, whereas, only few in Asian countries that tested an event that align to the environment, especially in Bali (Astawa et al., 2018). The assessment on green event variable related to the harmonious culture with environment was conducted on location or event venue, energy used, water management, catering, event promotion methods, materials used in the event, and waste management. The measurement of location or event venue was associated with the area used and tent structure used, which was whether or not the tent had plastic straps.

The use of plastic wrap is usually considered as unfriendly to environment. Installed signage and communication aimed to elucidate environmental preservation and environmental improvement practices in the event. There was one differential measurement item found in the location variable, which was whether or not the location used was sacred since it associated with the community belief that a sacred place cannot be used and it could have bad impact on the implementation. Location allowed for the activities was a non-sacred location determined by each village with the permission of the head of the customary village. The research result contributed to the social capital theory stating that the establishment of a company is influenced by position or place (Lin, 2001). Another contribution related to event conducted in an area having various cultures was that it can be used as a new competitive strategy due to the cultural uniqueness as a differentiator. (Porter, 2008; Madsen, 2015). Energy variable measured consisted of environmental certification ownership, energy classification score, and energy consumption. The three indicators were explained through the amount of electricity saved, the use of renewable energy, the amount of oil saved, and the existence of electricity generators. Water management variable was measured through the use of water for drinking and event activities for the booths. In catering variable, indicators assessed including the catering company, materials used and types of food and beverage produced.

The three indicators of catering would be assessed regarding the distance of the catering company to the event venue (zero km company), Eco-friendly materials, Ecofriendly dishes, Packaging, Organic products , Fair trade products, Seasonal products , Zero $\mathrm{km}$ products, Fruit and vegetables, Bread, pasta, rice and by-products, animal products, certified fish ownership, and food wastage arrangement. Regarding promotional giveaways, the giveaways were presented during the event. The promotional giveaways variable was measured based on the form of promotion, namely: non-food, food, and food packaging form. In non-food, the assessment was related to the percentage of eco-friendly products and percentage of fair-trade products. Items assessed in food promotion giveaways included Organic products, Zero km products, and Seasonal products. Food packaging consisted of non-plastic materials, thus it indicated an apparent alignment to the environment.

The use of less plastic materials is expected in the green event. The materials used were included in the event variable that consisted of Flowers/plants, Paper, brochures and documents, and detergent. The use of flowers/plants comprised of Endemic seasonal species and Zero km, whereas paper, brochures, and documents included items of Recycled /environmentally certified paper, Electronic format, and Double-sided printing. Regarding detergent items, the assessment was related to Eco-friendly products and Other Ecofriendly products. Waste management variable was assessed on whether or not waste management existed and items observed was Reused and reusable products. The research result integrated the application of harmonious culture. Compared to a research by Boggia et al., (2018) and Astawa et al., (2018), there was a development of variables in measuring green event, which was belief system and cultural values variables. Cultural values and 
belief were the determinants of human behavior in conducting business activities (Schein, 2004; Yousef, 2000). The development of an easy-to-understand performance measurement model was a way to facilitate human action; therefore, sustainable concept in an event can be implemented well. The update of the finding supported sustainable tourism concept that considered cultural value as an indicator (Kapera, 2018). A perfect tool is meaningless if human behavior have no culture that align to the environment. This model will raise awareness that event assessment is essential. The quantitative result based on questionnaire distribution to green event organizers indicated that $86 \%$ of the organizers held bachelor's degree and the remaining were graduated from senior high school. The average of tenure was three (3) years and average age was 47 years old of $75 \%$ and the remaining was 48 years and above. Based on education, the organizers had adequate education to run management concept since higher education would mean deeper abilities to solve various problems (Dwi Atmanti, 2005). In addition, it was supported by their age where most of them were in the productive age; therefore, green event development concept could function well.

Table 4. Respondents' opinion on harmonious culture-based green event (Source: Processed primary data, 2018)

\begin{tabular}{|c|c|c|c|c|c|c|c|c|}
\hline Variable & Question items & \begin{tabular}{|c|} 
STS \\
1 \\
\end{tabular} & $\begin{array}{c}\mathrm{TS} \\
2 \\
\end{array}$ & $\begin{array}{c}\mathrm{RR} \\
3\end{array}$ & $\begin{array}{l} \\
4 \\
\end{array}$ & $\begin{array}{c}\text { SS } \\
5 \\
\end{array}$ & \begin{tabular}{|c} 
Total \\
(weight $x$ freq)
\end{tabular} & Average \\
\hline \multirow{3}{*}{$\begin{array}{l}\text { Harmony } \\
\text { with God }\end{array}$} & Conduct congregation & & & 6 & 20 & 56 & 378 & 4,61 \\
\hline & Involvement with the customs & & & 2 & 25 & 55 & 381 & 4,65 \\
\hline & Average & & & & & & & 4,63 \\
\hline \multirow{5}{*}{$\begin{array}{c}\text { Harmony } \\
\text { with } \\
\text { human }\end{array}$} & On foot/public transportation/car sharing & & & 5 & 22 & 55 & 378 & 4,61 \\
\hline & Not by car & & & 4 & 30 & 48 & 372 & 4,54 \\
\hline & By bicycle & & & 2 & 25 & 55 & 381 & 4,65 \\
\hline & Green support & & & 2 & 25 & 55 & 381 & 4,65 \\
\hline & Average & & & & & & & 4,61 \\
\hline
\end{tabular}

Based on Table 4 and 5, the event organizers had understood the green component outlined in event organizing, it was proven by the average value of each question item that was larger than four (4), which was closer to strongly agree. The research result had supported the implementation of sustainable tourism through natural preservation (Getz, 2009; Hall, 2011; Musgrave, 2011). Items used in assessing event activities were in line with concept developed by Boggia et al., (2018); Astawa et al., (2018); Raj \& Musgrave, (2009); Leuenberger \& Jungbluth, (2009) and FAO, (2013). An interesting finding in the research was items of green measurement of an event were more towards environmental approach or harmonization with natural environment, whereas harmonization with human and belief values in customs only had six items. Belief or cultural values were predominant in supporting green behavior in green event. It was indicated by the average value of questionnaire that was closer to strongly agree.

The community attitude that believed in the cultural values was in line with a research developed by Hofstede, (1991); Siagian, (2002) stated that cultural values of a region or nation are crucial in community's character building. Belief and humanity values approaches became the main differentiator from the previous finding. The result of assessment on event organizers in implementing green event was closer to strongly agree to the attribute proposed. It means that the event organizers had commitment to support environmental alignment due to global demand as well as its environmentalalignment culture. These two pressures had been understood and believed that no matter how great a measurement is without a strong support from human or less benefits would make the guidance is meaningless (Hall \& Hodges, 1996). 
Table 5. Respondents' opinion on harmonious culture-based green event (Source: Processed primary data, 2018)

\begin{tabular}{|c|c|c|c|c|c|c|c|c|}
\hline Variable & Question Item & $\begin{array}{c}\text { STS } \\
1\end{array}$ & $\begin{array}{c}\mathrm{TS} \\
2\end{array}$ & $\begin{array}{c}\mathrm{RR} \\
3\end{array}$ & $\begin{array}{l}S \\
4\end{array}$ & $\begin{array}{c}\text { SS } \\
5\end{array}$ & $\begin{array}{c}\text { Total } \\
\text { (weight } x \text { freq) }\end{array}$ & Average \\
\hline \multirow{34}{*}{$\begin{array}{c}\text { Harmony } \\
\text { with natural } \\
\text { environment }\end{array}$} & Saved space used & & & & 25 & 57 & 385 & 4,70 \\
\hline & Holy/sacred places & & & & 45 & 37 & 365 & 4,45 \\
\hline & Electricity saved & & & & 32 & 50 & 378 & 4,61 \\
\hline & Renewable energy & & & 5 & 20 & 57 & 380 & 4,63 \\
\hline & Fuels saved & & & 5 & 40 & 37 & 360 & 4,39 \\
\hline & Electricity generators & & & 2 & 30 & 50 & 376 & 4,59 \\
\hline & Non-potable & & & 6 & 30 & 46 & 368 & 4,49 \\
\hline & Drinking & & & 5 & 20 & 57 & 380 & 4,63 \\
\hline & Eco-friendly materials & & & 5 & 40 & 37 & 360 & 4,39 \\
\hline & Eco-friendly dishes & & & 2 & 30 & 50 & 376 & 4,59 \\
\hline & Packaging & & & 6 & 30 & 46 & 368 & 4,49 \\
\hline & Organic products & & & 5 & 40 & 37 & 360 & 4,39 \\
\hline & Fair trade products & & & 2 & 30 & 50 & 376 & 4,59 \\
\hline & Seasonal products & & & 6 & 30 & 46 & 368 & 4,49 \\
\hline & Zero km products & & & 5 & 20 & 57 & 380 & 4,63 \\
\hline & Fruit and vegetables & & & 5 & 40 & 37 & 360 & 4,39 \\
\hline & Bread, pasta, rice and by-products & & & 2 & 30 & 50 & 376 & 4,59 \\
\hline & Animal products & & & 5 & 40 & 37 & 360 & 4,39 \\
\hline & Certified fish & & & 2 & 30 & 50 & 376 & 4,59 \\
\hline & Food wastage & & & 6 & 30 & 46 & 368 & 4,49 \\
\hline & Eco-friendly products & & & 5 & 20 & 57 & 380 & 4,63 \\
\hline & Fair trade products & & & 5 & 40 & 37 & 360 & 4,39 \\
\hline & Organic products & & & 2 & 30 & 50 & 376 & 4,59 \\
\hline & Zero km products & & & 5 & 40 & 37 & 360 & 4,39 \\
\hline & Seasonal products & & & 2 & 30 & 50 & 376 & 4,59 \\
\hline & Endemic seasonal species & & & 6 & 30 & 46 & 368 & 4,49 \\
\hline & Zero km & & & 5 & 20 & 57 & 380 & 4,63 \\
\hline & $\begin{array}{l}\text { Recycled/environmentally } \\
\text { certified paper }\end{array}$ & & & 5 & 40 & 37 & 360 & 4,39 \\
\hline & Electronic format & & & 2 & 30 & 50 & 376 & 4,59 \\
\hline & Double-sided printing & & & 5 & 40 & 37 & 360 & 4,39 \\
\hline & Eco-friendly products & & & 2 & 30 & 50 & 376 & 4,59 \\
\hline & Other Eco-friendly products & & & 6 & 30 & 46 & 368 & 4,49 \\
\hline & Reused and reusable products & & & 5 & 20 & 57 & 380 & 4,63 \\
\hline & Average & & & & & & & 4,52 \\
\hline
\end{tabular}

Note: STS (strongly disagree); TS (disagree); RR (average); S (agree); ST (strongly agree)

The condition would damage the environment, community, and the already established cultural order (Hall \& Hodges, 1996; Small et al., 2005). Green event measurement model as explained in (Table 4) and (Table 5) was implemented to assess an event organized by an education institution, which was State Polytechnic of Bali in Pinge tourism village. The event was Culture and Tourism International Camps (Cultic) with participant of 147 people (Astawa et al., 2018). Result of the event assessment can be explained in (Table 6). The result of event assessment as explained in Table 6 indicates the components of harmonious culture related to belief in the greatness of God through prayer activity or prayer before an activity. Every participant prayed based on their own belief and it had been conducted routinely before the beginning and end of the activity. Every participant in the event was directly involved in ceremonial or cultural activities in the village to maintain the balance of the nature through the preparation of ceremonial set. 
Developing a Harmonious Culture-Based Sustainable Event Model in Bali Tourism Village

Table 6. Result of Cultic Event Evaluation (Source: Processed data, 2018)

\begin{tabular}{|c|c|c|c|}
\hline Harmonious Culture & Green Event Variables & Item Detail & Value \\
\hline \multirow{2}{*}{ Harmony with God } & Belief system & Congregation & $87 \%$ \\
\hline & Cultural values & Involvement in customary activities & $89 \%$ \\
\hline \multirow{4}{*}{$\begin{array}{l}\text { Harmony with } \\
\text { Human }\end{array}$} & Internal travel & On foot/public transport/car sharing & $100 \%$ \\
\hline & \multirow{2}{*}{ Participatory approach } & By car & No \\
\hline & & By bicycle & Yes \\
\hline & Villagers & Green support & $100 \%$ \\
\hline \multirow{33}{*}{$\begin{array}{c}\text { Harmony with } \\
\text { natural } \\
\text { environment }\end{array}$} & \multirow{2}{*}{ Location } & Saved space used & $75 \%$ \\
\hline & & Holy / sacred place & $100 \%$ \\
\hline & \multirow{4}{*}{ Energy } & Electricity saved & $15 \%$ \\
\hline & & Renewable energy & $\mathrm{O} \%$ \\
\hline & & Fuels saved & $\mathrm{O} \%$ \\
\hline & & Electricity generators & No \\
\hline & \multirow{2}{*}{ Water management } & Non-potable & $15 \%$ \\
\hline & & Drinking & No \\
\hline & \multirow{3}{*}{ Catering } & Eco-friendly materials & $97 \%$ \\
\hline & & Eco-friendly dishes & $95 \%$ \\
\hline & & Packaging & $25 \%$ \\
\hline & \multirow{3}{*}{ Promotional giveaways } & Organic products & $100 \%$ \\
\hline & & Fair trade products & $56 \%$ \\
\hline & & Seasonal products & $76 \%$ \\
\hline & \multirow{16}{*}{ Materials } & Zero km products & $88 \%$ \\
\hline & & Fruit and vegetables & $75 \%$ \\
\hline & & Bread, pasta, rice and by-products & $60 \%$ \\
\hline & & Animal products & \\
\hline & & Certified fish & Not used \\
\hline & & Food wastage & $0 \%$ \\
\hline & & Eco-friendly products & $67 \%$ \\
\hline & & Fair trade products & $45 \%$ \\
\hline & & Organic products & $76 \%$ \\
\hline & & Zero km products & Not used \\
\hline & & Seasonal products & Not used \\
\hline & & Endemic seasonal species & Not used \\
\hline & & Zero km & Not used \\
\hline & & Recycled/environmentally certified paper & Not used \\
\hline & & Electronic format & $78 \%$ \\
\hline & & Double-sided printing & Not used \\
\hline & \multirow{3}{*}{ Waste management } & Eco-friendly products & $100 \%$ \\
\hline & & Other Eco-friendly products & $100 \%$ \\
\hline & & Reused and reusable products & $100 \%$ \\
\hline
\end{tabular}

Cultural activity integrated with religious values believed by the village was something unique from the participants' point of view since they could feel how to be a villager. In addition, it was in line with sustainable tourism concept where one of its indicator element is cultural preservation (Yuan Pan, 2018). Regarding harmonious relationship with human, it could be seen that participants used less fuel-powered transportation and preferred to use bicycle as the transportation mode and they could mingle with the community well. The villagers welcomed them and supported the event that aligned to environmental preservation. It was also related to the culture from their ancestor that they have to stay in harmony with the nature if they want to achieve happiness. The culture was manifested in rituals or ceremonies for plants, animals, and soil 
or the surrounding nature. Natural preservation concept through culture was practiced together with the event participants thus the event gave positive impact (Getz \& Page, 2014; Wilson et al., 2017) on the community in terms of cultural preservation and economy (Chirieleison et al., 2013; Connell et al., 2015). Community involvement in the green event became the strength in cultural sustainability (Fanni \& Rezazadeh, 2018) that could be explained through several indicators in the event conducted at Pinge tourism village. Those indicators were rural tourism, cultural tourism, and heritage integrity. The integration of the three indicator components became the attraction for tourists who involved in the Cultic event. Therefore, the dominance of relationship with God and human was apparent, whereas relationship with the nature that had thirty indicators and adopted previous study, such as Boggia et al., (2018), was nonexistent since the event was adjusted to the village culture that dominated by simplicity thus many indicators were not used unlike those events in Italy, America, and Swiss (Rowley et al., 2012).

Harmonization with the nature in the event implementation had updated indicator, which was the event venue that followed tri mandala concept. The venue was divided into three parts, the main part, middle, and end part. The main part is a sacred or holy place; therefore, event activities could not be conducted at this place. Thus it left the middle and end parts that could be used. Every village had this type of area division using the concept and it was arranged in the village customary rules (Windia \& Ratna, 2007). Although the selection of event venue used cultural concept, it also used modern indicators and raised tourism concepts at the village, such as eco-tourism, low carbon tourism, and other tourism alternatives. Cultural based event assessment was easy to understand by the guests since the event was simple and it was adjusted to the existing village culture. Moreover, before the implementation of the event, the event framework that should be followed had been distributed. Another model used had high difficulty level, such as eco-event evaluation. The evaluation is hard to understand for common people as well as the experts (Collins \& Flynn, 2008; Collins et al., 2009). The form of tourism sustainability reporting that includes inputoutput in one of environmental aspects mathematically (Parkes et al., 2016) is difficult to understand. This model was developed through the culture of an area where the event was conducted thus community involvement was the objective in the sustainable tourism (Smith-Cristensen, 2009). Through the model, the event organizers had similar view with the community regarding green event; thus, it facilitated the implementation of environmental preservation programs from the government as well as world environmental organizations. The green event measurement model would support cultural tourism developed by Bali. It could also a competitive strategy that has differentiators in assessing green event; thus, it supports competitive strategy theory from Porter (2008).

\section{CONCLUSION}

Harmonious culture-based green event measurement model had twelve variables agreed as one of alternatives in assessing an event conducted in the tourism village. Tourism village concept referred to a community-based tourism (CBT), which is a form of tourism that seeks to empower communities to manage tourism growth and achieve community aspirations relating to their well-being, and includes economic, social and environmental sustainable development. The model development was an innovation to support the CBT concept by considering cultural values in the society.

Harmonious culture used to measure event was an innovation in environmental management that put community culture forward in organizing an event. The concept encouraged sustainable development that required support from all parties to save the world from pollution. One indicator of success of the sustainable development is culture; therefore, cultural-based measurement in sustainable tourism development is 
appropriate. The calculation model integrated modern and traditional measures or local culture in Bali. The concept was in line with cultural tourism developed by the government. To refine the measurement model would require further research from various perspectives, such as economy. Currently, at least there is a reference to assess event activity that supports environment with community participation and culture.

The model has an opportunity to be developed in a simpler direction in terms of items used by classifying types and forms of event; thus it will be uncomplicated and easier to understand. Model measurement with community participation and culture would require an observation on the involvement of government, tourism association, and supplier in building sustainable indicators of an event.

\section{Aknowlegments}

The authors would like to send their gratitude to the Indonesian Government for the research funding as well as to the head of $\mathrm{P}_{3} \mathrm{M}$ that gave motivation to complete the research. Also, the authors would like to thanks the local Goverment for their participation in the model test.

\section{REFERENCES}

Adema, K., \& Roehl, W. (2010). Environmental scanning the future of event design. International Journal of Hospitality Management, 29(2), 199-207.

Ahmed, F., \& Pretorius, L. (2010). Mega-events and environmental impacts: The 2010 FIFA World Cup in South Africa. Alternation, $17(2)$.

Andersson, T. D., \& Lundberg, E. (2013). Commensurability and sustainability: Triple impact assessments of a tourism event. Tourism Management, 37, 99-109.

Arcodia, C., Cohen, S., \& Dickson, C. (2012). Accrediting sustainable event practice. In E. Fayos-solà (Ed.), Knowledge management in tourism: Policy and governance applications (pp. 209-218). Bingley: Emerald Group.

Arnegger, J., \& Herz, M. (2016). Economic and destination image impacts of mega-events in emerging tourist destinations. Journal of Destination Marketing \& Management.

Astawa P. I. \& Sudika P., (2014). The Impact Local Culture on Financial Performance in Property Firms in Bali, Asia Pacific Management and Business Application, 3(2), 106-115.

Astawa, I. P., Triyuni, N. N., \& Santosa, I.D.M.C. (2018, January). Sustainable tourism and harmonious culture: a case study of cultic model at village tourism. In Journal of Physics: Conference Series (Vol. 953, No. 1, p. 012057). IOP Publishing.

Boggia A., Massei G., Paolotti L., Rocchi L., \& Schiavi F. (2018). A model for measuring the environmental sustainability of events. Journal of Environmental Management. 206, 836-845.

Boo, S., \& Busser, J. (2005). Impact analysis of a tourismfestival on tourists destination images. Event Management, 9(4), 223-237.

Bracalente, B., Chirieleison, C., Cossignani, M., Ferrucci, L., Gigliotti, M., \& Giovanna Ranalli, M. (2011). The economic impact of cultural events: The Umbria Jazz music festival. Tourism Economics, 17(6), 1235-1255.

Buckley, R. (2012). Sustainable tourism: Research and reality. Annals of Tourism Research, 39(2), 528-546.

Burgan, B., \& Mules, T. (2001). Reconciling cost-benefit and economic impact assessment for event tourism. Tourism Economics, 7(4), 321-330.

Carlsen, J., Getz, D., \& Soutar, G., (2001). Event evaluation research. Event Management. 6, 247-257.

Case, R., (2013). Events and the Environment. Routledge, London.

Chen, S. (2011). Residents' perceptions of the impact of major annual tourism events in Macao: Cluster analysis. Journal of Convention \& Event Tourism, 12(2), 106-128.

Chirieleison, C., Montrone, A., \& Scrucca, L. (2013). Measuring the impact of a profitoriented event on tourism: The Eurochocolate festival in Perugia, Italy. Tourism Economics, 19(6), 1411-1428.

Chirieleison, C., \& Montrone, A. (2013). Evaluating local government costs and revenues: The case of an Italian privately owned for-profit event. Tourism Management Perspectives, 8, 90-97.

Clarke, J. (1997). A framework of approaches to sustainable tourism. Journal of Sustainable Tourism, 5(3), 224-233.

Creswell, J. W., \& Clark, V. L. P. (2017). Designing and conducting mixed methods research. Sage publications.

Collins, A., \& Flynn, A., (2008). Measuring the environmental sustainability of a major sporting event: a case study of the FA Cup Final. Tourism Economic. 14 (4), 751-768.

Collins, A., Jones, C., \& Munday, M. (2009). Assessing the environmental impacts of mega sporting events: Two options? Tourism Management, 3o(6), 828-837

Connell, J., Page, S. J., \& Meyer, D. (2015). Visitor attractions and events: Responding to seasonality. Tourism Management, 46, 283-298

De Bres, K., \& Davis, J. (2001). Celebrating group and place identity: A case study of a new regional festival. Tourism Geographies, 3(3), 326-337. 
Delamere, T. (1997). Development of scale items to measure the social impact of community festivals: Item generation. Journal of Applied Recreation Research, 22(4), 293-315.

Derrett, R. (2003). Making sense of how festivals demonstrate a community's sense of place. Event Management, 8(1), 49-58.

Dolles, H., \& Söderman, S. (2010). Addressing ecology and sustainability in mega-sporting events: The 2006 football World Cup in Germany. Journal of Management \& Organization, 16, 587-600.

Dolf, M., \& Teehan, P. (2015). Reducing the carbon footprint of spectator and team travel at the University of British Columbia's varsity sports events. Sport Management Review, 18(2), 244-255.

Dredge, D., \& Whitford, M. (2010). Policy for sustainable and responsible festivals and events: Institutionalisation of a new paradigm - A response. Journal of Policy Research in Tourism, Leisure and Events, 2(1), 1-13.

Dwi Atmanti, H. (2005). Investment in human resources through education. Jurnal Dinamika Pembangunan (JDP). 2(1), 30-39.

Dwyer, L., Forsyth, P., \& Spurr, R. (2006a). Assessing the economic impacts of events: A computable general equilibrium approach. Journal of Travel Research, 45(1), 59-66

Dwyer, L., Forsyth, P., \& Spurr, R. (2006b). Economic impact of sport events: A reassessment. Tourism Review International, 10(4), 207-216.

Dwyer, L., Mellor, R., Mistilis, N., \& Mules, T. (2000a). A framework for assessing "tangible"and "intangible" impacts of events and conventions. Event Management, 6(3), 175-189.

Dwyer, L., Mellor, R., Mistilis, N., \& Mules, T. (200ob). Forecasting the economic impacts of events and conventions. Event Management, 6(1), 192-204.

Elkington, J. (1997). Cannibals with forks. The triple bottom line of 21st century. Oxford: Capstone.

Fanni, Z., \& Rezazadeh S. M. (2018). Analysing The Urban Environment Sustainability Influenced by Tourism in Iran (District 1 of Teheran Metropolis). GeoJournal of Tourism and Geosites, 23(3), 719-730.

FAO, 2013. Food Wastage Footprint: Impact on Natural Resource. Summary report.FAO.

Felsenstein, D., \& Fleischer, A. (2003). Local festivals and tourism promotion: The role of public assistance and visitor expenditure. Journal of Travel Research, 41, 385-392.

Franzoni, S. (2015). Measuring the sustainability performance of the tourism sector. Tourism Management Perspectives, 16, 22-27.

Fredline, E., Raybould, M., Jago, M., \& Deery, M. (2005). Triple bottom line event evaluation: A proposed framework for holistic event evaluation. In J. Allen (Ed.), The impact of events, proceedings of international event research conference. Sidney: Australian Centre for Event Management

Fredline, E., \& Faulkner, B. (2000). Host community reactions. Annals of Tourism Research, 27(3), 763-784.

Gaffney, C. (2013). Between discourse and reality: The un-sustainability of mega-event planning. Sustainability, 5(9), 3926-3940.

Galli, A., Wackernagelb, M., Ihac, K., \& Lazarus, E., (2014). Ecological Footprint: implications for biodiversity. Biology. Conservation. 173, 121-132.

Getz, D., 2008. Event tourism: definition, evolution and research. Tourism Management 29 (3), 403-428.

Getz, D., (2009). Policy for sustainable and responsible festivals and events: institutionalization of a new paradigm. Journal of Policy Research in Tourism, Leisure and Events. 1 (1), 61-78.

Getz, D., Andersson, T., \& Carlsen, J. (2010). Festival management studies: Developing a framework and priorities for comparative and cross-cultural research. International Journal of Event and Festival Management, 1(1), 29-59.

Getz, D., \& Page, S. J. (2014). Progress and prospects for event tourism research. Tourism Management, 52, $593-631$.

Glaser, B. G., \& Strauss, A. L. (2017). Discovery of grounded theory: Strategies for qualitative research. Routledge.

Gössling, S., Hansson, C., Hörstmeier, O., \& Saggel, S. (2002). Ecological footprint analysis as a tool to assess tourism sustainability. Ecological Economics, 43(2), 199-211.

Hair Jr, J. F., Hult, G. T. M., Ringle, C., \& Sarstedt, M. (2016). A primer on partial least squares structural equation modeling (PLS-SEM). Sage Publications.

Hall, C. M., \& Hodges, J. (1996). The party's great, but what about the hangover? The housing and social impacts ofmegaevents with special reference to the 2000 Sydney Olympics. Festival Management and Event Tourism, 4(1), 13-20.

Hall, C. (2011). Policy learning and policy failure in sustainable tourismgovernance: From first-and secondorder to third-order change? Journal of Sustainable Tourism, 19(4-5), 649-671.

Hall, C. (2012). Sustainable mega-events: Beyond the myth of balanced approaches to mega-event sustainability. Event Management, 16(2), 119-131.

Heitmann, S., \& Dávid, L. (2010). Sustainability and events management (pp. 181-20o). In P. Robinson, G. Dickson, \& D. Wale (Eds.), Events Management. Wallingford: CABI.

Henama, U.S., \& Apleni, L. (2018). A Theoretical Approach Into Tourism, Immigration and Multiculturalism: The Case of South Africa. GeoJournal of Tourism and Geosites. 23(3), 772-779

Hofstede, G. (1983). National cultures in four dimensions: A research-based theory of cultural differences among nations. International Studies of Management \& Organization, 13(1-2), 46-74.

Hofstede, G. (2001). Culture's Consequences: Comparing Values, Behaviors, Institutions, and Organizations Across Nations (2nd ed.). Sage Publications.

Hofstede, G. (1991). Measuring Organizational Cultures: A Qualitative and Quantitative Study Acros Twenty Cases, Administrative Science Quarterly; 35, 2; pg. 286 
Hottle, T., Bilec, M., Brown, N., \& Landis, A. (2015). Toward zero waste: Composting and recycling for sustainable venue based events. Waste Management, 38, 86-94.

Hunter, C. (1997). Sustainable tourism as an adaptive paradigm. Annals of Tourism Research, 24(4), 850-867.

Hunter, C., \& Green, H. (1995). Tourism and the environment: A sustainable relationship? London: Routledge

Jansen-Verbeke, M. (2009). The territoriality paradigm in cultural tourism. Tourism, 19(1-2), 25-31. http://dx.doi.org/10.2478/V10106-009-0003-z.

Jones, M. (2014). Sustainable event management: A practical guide. London: Routledge.

Kapera, I. (2018). Sustainable tourism development efforts by local governments in Poland. Sustainable Cities and Society, $40,581-588$.

Kay Xin, T., Chan, J. K. L., Vogt, C. A., \& Mohamed, B. (2016). Comprehending the responsible tourism practices through principles of sustainability: A case of Kinabalu Park. Tourism Management Perspectives, 18, 34-41.

Kim, W., Jun, H. M., Walker, M., \& Drane, D. (2015). Evaluating the perceived social impacts of hosting largescale sport tourism events: Scale development and validation. Tourism Management, 48, 21-32.

Kozoviy, V. (2018). Cultural Aspect of Sentimental Tourism Within Ukrainian-Polish Border. GeoJournal of Tourism and Geosites, 23(3), 668-674

Kulshrestha, U. C., Nageswara Rao, T., Azhaguvel, S., \& Kulshrestha, M. J. (2004). Emissions and accumulation of metals in the atmosphere due to crackers and sparkles during Diwali festival in India. Atmospheric Environment, 38(27), 4421-4425. http://dx.doi.org/10.1016/j.atmosenv.2004.05.044.

Kuo, C., Lee, H., \& Lai, J. (2006). Emission of polycyclic aromatic hydrocarbons and lead during Chinese midautumn festival. Science of the Total Environment, 366(1), 233-241.

Lee, H., \& Graefe, A. R. (2003). Crowding at an arts festival: Extending crowdingmodels to the frontcountry. Tourism Management, 24(1), 1-11.

Lee, M. (2007). Analytical reflections on the economic impact assessment of conventions and special events. Journal of Convention \& Event Tourism, 8(3), 71-85.

Lee, C., \& Taylor, T. (2005). Critical reflections on the economic impact assessment of a mega-event: The case of 2002 FIFAWorld Cup. Tourism Management, 26(4), 595-603.

Leuenberger, M., \& Jungbluth, N., (2009). Okoprofil von vegetarischen und fleischhaltigen Grossküchenmahlzeiten. ESU-services GmbH im Auftrag des WWF Schweiz, Uster, CH.

Lin N, (2001). Social Capital: A Theory of Social Structure and Action. Cambridge, New York: Cambridge University Press.

Liyin, S., Hong, Y., \& Griffith Lim, W. M. (2016). Creativity and sustainability in hospitality and tourism. TourismManagement Perspectives, 18, 161-167.

Lindberg, K., McCool, S., \& Stankey, G. (1997). Rethinking carrying capacity. Annals of Tourism Research, 24, $461-465$.

Liyin, S., Hong, Y., \& Griffith, A., (2006). Improving environmental performance by means of empowerment of contractors. Management of Environmental Quality: An International Journal. 17,242-257.

Madsen, T. L., \& Walker, G. (2015). Modern competitive strategy. McGraw Hill.

Maia de Souza, D., Flynn, D.F.B., DeClerck, F., Rosenbaum, R.K., de Melo Lisboa, H., \& Koellner, T., (2013). Land use impacts on biodiversity in LCA: proposal of characterization factors based on functional diversity. The International Journal of Life Cycle Assessment. 18, 1231-1242.

Martín-Pena, M.L., Díaz-Garrido, E., \& Sanchez-Lopez, J.M., (2014). Analysis of benefits and difficulties associated with firms' Environmental Management Systems: the case of the Spanish automotive industry. Journal of Cleaner Production. 70, 220-230.

McCartney, G., \& Osti, L. (2007). From cultural events to sport events: A case study of cultural authenticity in the dragon boat races. Journal of Sport Tourism, 12(1), 25-40.

Mika, M. (2015). Sustainable tourism: a critique of the academic feasibility of the concept. Turyzm, 25(1), 9-17.

Miles, M. B., Huberman, A. M., Huberman, M. A., \& Huberman, M. (1994). Qualitative data analysis: An expanded sourcebook. Sage.

Mohd Shariff, N., Zainol Abidin, A., \& Mohamed, A.E., (2019). Tourism Event: Perceptions on The Critical Indicators of Climate Variabelity and Change in Malaysia. GeoJournal of Tourism and Geosites, 24(1), 39-47.

Mules, T., \& Dwyer, L. (2005). Public sector support for sport tourism events: The role of cost-benefit analysis. Sport in Society, 8(2), 338-355.

Musgrave, J. (2011). Moving towards responsible events management. Worldwide Hospitality and Tourism Theme, 3(3), 258-274.

Nidumolu, R., Prahalad, C. K., \& Rangaswami, M. R. (2009). Why sustainability is now the key driver of innovation. Harvard business review, 87(9), 56-64.

Okech, R. (2011). Promoting sustainable festival events tourism: A case study of Lamu Kenya. Worldwide Hospitality and Tourism Theme, 3(3), 193-202.

O'Reilly, A. (1986). Tourism carrying capacity: Concept and issues. Tourism Management, 7, 254-258

O'Sullivan, D., \& Jackson, M. (2002). Festival tourism: A contributor to sustainable local economic development? Journal of Sustainable Tourism, 10, 325-342.

Parkes, O., Lettieri, P., \& Bogle, I.D.L., (2016). Defining a quantitative framework for evaluation and optimization of the environmental impacts of mega-event projects. Journal of Environmental Management. 167, 236-245. 
Porter, M. E. (2008). Competitive strategy: Techniques for analyzing industries and competitors. Simon and Schuster Raj, R., \& Musgrave, J., (2009). The Economics of Sustainable Events. In: Raj, R., Musgrave, J. (Eds.), Event Management and Sustainability, CABI, Wallingford.

Richards, G. (2007). Culture and authenticity in a traditional event: The views of producers, residents, and visitors in Barcelona. Event Management, 11(1), 33-44.

Ritchie, J. R. B., \& Beliveau, D. (1974). Hallmark events: An evaluation of a strategic response to seasonality in the travel market. Journal of Travel Research, 13(2), 14-20.

Rollins, R., \& Delamere, T. (2007). Measuring the social impact of festivals. Annals of Tourism Research, 34, 805-808.

Rowley, H.V., Peters, G.M., Lundie, S., \& Moore, S.J., (2012). Aggregating sustainability indicators: beyond the weighted sum. Journal of Environmental Management, 111, 24-36.

Schein, E. H. (2004). Organizational Culture and Leadership, John Wiley and Sont.Inc

Siagian, S. P. (2002). Management of human resources. Jakarta. Alphabet Earth.

Small, K. (2007). Social dimensions of community festivals: An application of factor analysis in the development of the social impact perception (SIP) scale. Event Management, 11(1-2), 45-55.

Small, K., Edwards, D., \& Sheridan, L. (2005). A flexible framework for evaluating the socio-cultural impacts of a (small) festival. International Journal of Event Management Research, 1(1), 66-77.

Smith-Cristensen, C. (2009). Sustainability as a concept within events. In R. Raj, \& J. Musgrave (Eds.), Event management and sustainability. New York: Cabi.

Stettler, S. (2011). Sustainable event management of music festivals: An event organizer perspective. (Dissertations and Theses) Paper 257 (edu/open_access_etds/257).

Taks, M. (2013). Social sustainability of non-mega sport events in a global world. EJSS. European Journal for Sport and Society, $10(2), 121$.

Tang, S. Y., Lo, C. H., Cheung, K. C., \& Lo, J.M.K. (2009). Institutional constraints on environmental management in Urban China: Environmental impact assessment in Guangzhou and Shanghai. China Quarterly, 152, 863.

Turk, A.M., (2009). ISO 14000 environmental management system in construction: an examination of its application in Turkey. Total Quality Management Business. Excellence. 20, 713-733.

Thompson, K., \& Matheson, C. (2008). Culture, authenticity and sport: A study of event motivations at the Ulaanbaatar Naadam festival, Mongolia. In J. Cochran (Ed.), Asian tourism: Growth and change (pp. 233-243). Oxford: Elsevier.

Tyrrel, B. J., \& Ismail, J. A. (2005). A methodology for estimating the attendance and economic impact of an open-gate festival. Event Management, 9(3), 111-118.

Xie, P. (2004). Visitors'perceptions of authenticity at a rural heritage festival: A case study. Event Management, $8(3), 151-160$.

Yousef, D. A. (2000). Organizational commitment as a mediator of the relationship between Islamic work ethic and attitudes toward organizational change. Human Relations, 53(4), 513-537.

Wackernagel, M., \& Rees, W. (1998). Our ecological footprint: Reducing human impact on the earth.

Waitt, G. (2003). Social impacts of the Sydney Olympics. Annals of Tourism Research, 3o(1), 194-215.

Wang, Y., Zhuang, G., Xu, C., \& An, Z. (2007). The air pollution caused by the burning of fireworks during the lantern festival in Beijing. Atmospheric Environment, 41(2), 417-431.

Whitson, D., \& Horne, J. (2006). Part 2 the Glocal politics of sports mega-events: Underestimated costs and overestimated benefits? Comparing the outcomes of sports mega-events in Canada and. The Sociological Review, 54, 71-89.

Wilson, J., Arshed, N., Shaw, E., \& Pret, T. (2017). Expanding the domain of festival research: A review and research agenda. International journal of management reviews, 19(2), 195-213

Wilson, J., \& Arshed, N. (2016). Expanding the domain of festival research: A review and research agenda. International Journal of Management Reviews.

Windia, W., \& Ratna K.D. (2007). Business Analysis Based on Tri Hita Karana, Publisher Universitas, Udayana, Denpasar.

Yuan Pan, S., Gao M., Kim H., Shah K.J., Lu Pei S., \& Chi Chiang P. (2018). Advance and Challenges in Sustainable Tourism Towards a Green Economy. Science of The Environment 635, 452-469.

Yuan, Y. Y. (2013). Adding environmental sustainability to the management of event tourism. International Journal of Culture, Tourism and Hospitality Research, 7(2), 175-183.

Zilahy, G. (2004). Organizational factors determining the implementation of cleaner production measures in the corporate sectors. , 12, 311-319.

*** Buku Panduan Tri Hita Karana Awards \& Accreditation, (2017). Bali Travel Newspaper Denpasar.

*** International Organization for Standardization, (2004). Environmental Management Systems-requirements with Guidance for Use. ISO 14001.

*** UNEP, ICLEI, IAMLADP, (2009). Green Meeting Guide. Roll out the Green Carpet for your Participants. United Nations Environment Programme.

Submitted:

17.02.2019
Revised:

07.05.2019
Accepted and published online 31.05.2019 